\title{
THE INDEPENDENT LIABILITY RULE AS A BAR TO INTERPLEADER IN THE FEDERAL COURTS*
}

INTERPLEADER is a remedy available to a stakeholder who is threatened by plural claims to the same obligation or chattel, and thus faces the possibility of multiple liability in separate actions against him by the claimants. ${ }^{1}$ In the first of the two stages of interpleader the stakeholder deposits the property into court or posts a bond and is discharged from further responsibility to the claimants.: In the second stage the claimants determine among themselves who is entitled to the money or property. ${ }^{3}$ In the federal courts there are two general interpleader remedies: the statutory procedure provided by the Interpleader Act of 1936, ${ }^{4}$ and the nonstatutory interpleader which developed in equity and is now governed by rule 22 of the Federal Rules of Civil Procedure." Statutory interpleader, available in disputes involving $\$ 500$ or more, requires diversity of citizenship only between the claimants and permits nationwide service of process. ${ }^{\circ}$ In diversity cases nonstatutory interpleader calls for a jurisdictional amount of at least $\$ 3,000$ and diversity between the stakeholder and the claimants; only the usual intrastate service of process is permitted. ${ }^{7}$ In equity practice the availability of interpleader came to be limited by several crippling conditions, ${ }^{8}$ all but one of which are clearly no longer applicable in

$\because$ Hurlbut v. Shell Oil Co., 131 F. Supp. 466 (W.D. La. 1955).

1. Even though one claimant may be successful against the stakeholder other claimants will not be barred from recovery in separate actions since only parties to an action are hound by a decree arising from it. Hughes v. Sun Life Assurance Co., 159 F.2d 110 (7th Cir. 1946) ; Botz v. Helvering, 134 F.2d 538 (8th Cir. 1943).

2. Chafee, Broadening the Second Stage of Interpleader, 56 Harv. L. REv. 541 (1943); MCClintuck, EQuity \$ 182 (2d ed. 1948).

3. Chafee, supra note 2, at 541; McClintock, EQuity $\$ 182$ (2d ed. 1948).

4. 28 U.S.C. $\$ \$ 1335,1397,2361$ (1952).

There are also four federal grants of interpleader which apply to special situations: conflicting claims against a carrier, 39 Stat. 541 (1916), 49 U.S.C. $\$ 97$ (1952) ; rival insurance claims against the Veterans' Administration, 43 STAT. 1303 (1925), as amended, 38 U.S.C. $\$ 445$ (1952); claims to marine war risk insurance proceeds, 64 STAT. 776 (1950), 46 U.S.C. $\$ 1292$ (1952) ; and claims to air commerce war risk insurance proceeds, 65 STAT. 68 (1951), 49 U.S.C. $\$ 720$ (1952).

Several of the states have codified interpleader. E.g., N.Y. CIv. PRAC. ACT $\S 285$.

5. See, generally, 3 M Ioore, Federal Practrce $\{22.02$ (2d ed. 1948).

Interpleader was initially developed in the common law courts. Rogers, Historical Origins of Interpleader, 51 Y ALE L.J. 924, 947-48 (1942). However it was soon taken over exclusively by the chancellor. Id. at 950 .

The old equitable interpleader is supplemented rather than replaced by the statutory remedy. 3 MLone, op. cit. supra $\{22.02$.

6. 28 U.S.C. $\$ \$ 1335,1397,2361$ (1952).

7. 28 U.S.C. $\$ 1332$ (1952); Clark, Code Pleading $\$ 66$ (2d ed. 1947).

8. " 1 . The same thing, debt, or duty must be claimed by both or all the parties against whom the relief is demanded; 2 . All their adverse titles or claims must be dependent, or lie derived from a common source; 3 . The person asking the relief-the plaintiff-must not 
the federal courts. ${ }^{9}$ The last of these restrictions-the independent liability rule-would bar interpleader if without regard to the rights of the claimants among themselves the stakeholder is separately liable to one or more of them. ${ }^{10}$ The problem has recently arisen whether the absence of an independent liability is still a requisite of statutory interpleader, and, if so, with what degree of certainty such a liability must be shown.

In Hurlbut $v$. Shell Oil Co.,11 the plaintiff sued Shell for royalties arising out of the leasing of oil lands. Shell, admitting liability for the royalties, claimed that it was unable to ascertain who was entitled to them and sought to interplead the plaintiff with third party defendants under the Federal Interpleader Act. The plaintiff and the third parties moved to dismiss the interpleader on the ground that aside from the validity of their royalty claims Shell would be independently liable to them on one of several alternative theories. ${ }^{12}$ Holding that an absence of independent liability was required for statutory interpleader, and that the allegations of the claimants concerning independent liability presented a "genuine issue as to law or fact," the court granted the motion to dismiss. ${ }^{13}$ The court did not state what the allegations were, ${ }^{14}$ and it refused to decide whether the claims presented were meritorious. The court's discussion indicates that the validity of the claims depended in part on un-

have nor claim any interest in the subject matter; 4. He must have incurred no independent liability to either of the claimants; that is, he must stand perfectly indifferently between them, in the position merely of a stakeholder." 4 POMERoY, EQUiTY Jurisprudence $\$ 1322$ (5th ed. 1941) ; see Chafee, Modernizing Interpleader, 30 YaLE L.J. \$14, 822 (1921).

9. The first three conditions cited in note 8 supra have now been abrogated. 28 U.S.C. $\S 1335$ (1952) ; Chafee, The Federal Interpleader Act of 1936: I, 45 YALE L.J. 963, 978-82 (1936).

10. Hurlburt v. Shell Oil Co., 131 F. Supp. 466 (W.D. La. 1955) ; Crawshay v. Thornton, 2 My. \& Cr. 1, 40 Eng. Rep. 541 (Ch. 1832).

Independent liability can arise either from an express agreement to be bound, Dee v. Kansas City Life Ins. Co., 86 F.2d 813 (7th Cir. 1936) (recognition by insurance company of the title of one of the claimants), or from operation of law based on a relationship of the stakeholder to a claimant, Lindsey v. Barron, 6 C.B. 291, 136 Eng. Rep. 1263 (1848) (implied warranty of authority to pledge). See also Poneroy, op. cit. supra note 8, $\$ 1326$; MacLennan, The Interplcader Doctrine of Independent Liability, 32 Arr. L. REv. 331, 33435 (1898). Liability, express or implied, may be either primary or secondary in nature. A primary liability is one which may be pursued by a claimant without regard to his rights to recovery as the true owner against other title claimants. See, e.g., Dee v. Kansas City Life Ins. Co., supra. A secondary liability is one which matures when a claimant averring it is unsuccessful on title. Lindsey v. Barron, supra.

11. 131 F. Supp. 466 (W.D. La. 1955).

12. The allegations of independent liability, not discussed in the court's opinion, were based on the theories that (1) Shell had negligently classified the oil wells on claimants' lands; (2) Shell had incorrectly classified the wells and in so doing had prejudiced the third party claimants; and (3) Shell had violated certain development clauses in the third parties' lease. Supplemental Memorandum for Defendants, p. 9, Huribut v. Shell Oil Co., 131 F. Supp. 466 (W.D. La. 1955).

13. Hurlburt v. Shell Oil Co., supra note 12, at 469.

14. The court merely stated that a "complicated question of law" had been presented. Ibid. See note 12 supra for the defendants' statement of the issues. 
settled issues of state law, not on questions of proof. It conceded that not every allegation of independent liability would defeat interpleader, indicating that "flimsy" and "transparent" contentions would not suffice. ${ }^{15}$ But without citation of authority the court concluded that a "substantial" question of fact or law was a bar to interpleader.

Hurlbut represents an extension of the usual independent liability rule and increases the possibility that a stakeholder will incur undeserved liability through multiple suits. Formerly, when interpleader was opposed by an allegation of independent liability, courts took evidence and determined the issue. ${ }^{10}$ Where no such liability was found interpleader was granted. ${ }^{17}$ But if it were proved interpleader would be denied; this, of course, would expose the stakeholder to the risk that other claimants might recover against him unjustly on their claims of title. ${ }^{18}$ In $H u r l b u t$, however, a "substantial" question of independent liability defeated interpleader. ${ }^{19}$ The opinion gives little indication of what constitutes an issue which is genuine or substantial enough to avoid interpleader. The category could not readily be limited to unsettled questions of state law. For federal courts in diversity cases may not refuse to assume jurisdiction or to decide cases merely because difficult questions of state law are involved. ${ }^{20}$ But if an allegation of any involved question of fact or law will satisfy the Hurlbut test, interpleader may become almost unavailable. And even though no independent liability is ever proved, the stakeholder

15. Hurlbut v. Shell Oil Co., 131 F. Supp. 466,468 (W.D. La. 1955).

16. Dee v. Kansas City Life Ins. Co., S6 F.2d 813 (7th Cir. 1936); Equitable Life Ins. Co. v. Gilman, 14 F.R.D. 243 (W.D. Mo. 1953) ; First State Bank v. Citizens State Bank, 10 F.R.D. 424 (D. Neb. 1950).

17. Dee v. Kansas City Life Ins. Co., supra note 16; Equitable Life Ins. Co. v. Gilman, 114 F. Supp. 387 (W.D. Mo. 1953).

18. Each claimant is free to proceed against the stakeholder in a separate action. And although the stakeholder should be liable to one of them if the claimant who was successful on the independent liability theory did not have good title, where there are more than two claimants the stakeholder may find several "proving" good title in different courts. Aside from the risk of multiple liability, the resulting multiplicity of suits will be wasteful both to the courts and the stakeholder. Maryland Cas. Co. v. Glassell-Taylor \& Robinson, 156 F.2d 519, 523 (5th Cir. 1946) ; Massachusetts Bonding \& Ins. Co. v. St. Louis, 109 F. Supp. 137, 139 (E.D. Mo. 1952). Moreover, denial of interpleader may lead to a race anong claimants, United States v. Sentinel Fire Ins. Co., 178 F.2d 217 (5th Cir. 1949), and a successful claimant may have to institute additional suits to quiet his title against rival claimants. See Atwood v. Kleberg, 133 F.2d 69 (5th Cir.), cert. denied, 320 U.S. 744 (1943).

19. Hurlbut v. Shell Oil Co., 131 F. Supp. 466,468 (W.D. La. 1955).

20. Meredith v. Winter Haven, 320 U.S. 228 (1943) ; Commonwealth Trust Co. v. Bradford, 297 U.S. 613 (1936). Although the jurisdiction granted by the Federal Interpleader Act is distinct from diversity jurisdiction, The Walmac Co. v. Isaacs, 220 F.2d 108 (1st Cir. 1955), the rationale of the diversity cases should be applicable to the Interpleader Act. Statutory interpleader is based on diversity between claimants, and the wording of the Act is mandatory. 28 U.S.C. $\$ 1335$ (1952), Railway Express Agency, Inc. v. Jones, 106 F.2d 341 (7th Cir. 1939). 
will be subjected to the risk of multiple liability on title claims that interpleader is intended to prevent.

A possible justification for the Hurlbut rule might be a policy of avoiding judicial "waste" attributable to the necessity of dismissing the interpleader after an affirmative finding of independent liability, without being able to award a judgment on that liability. ${ }^{21}$ For several reasons a court might be unable to grant the independent claimant a damage judgment against the stakeholder. The independent liability might be contingent, not maturing until some later event, such as an unsuccessful suit by the claimant against other claimants on his claim of title. ${ }^{22}$ Even if the liability were absolute, a court might consider itself without jurisdiction to render an affirmative award unless there was diversity between the claimant and stakeholder. ${ }^{23}$

However, neither of these objections is insuperable. While judgment could not be given where a contingent liability was shown, the affirmative finding of liability would be conclusive in a subsequent proceeding between the parties under the doctrine of collateral estoppel. ${ }^{24}$ Overlapping of judicial effort would be slight, since the party that proved independent liability in the interpleader suit could recover in a subsequent action merely by introducing the prior judgment and findings, and proving elements of the cause of action, such as damages, which were not previously at issue. ${ }^{25}$ And if the independent liability were absolute, lack of diversity should not bar a damage award. For it has long been clear that a federal court may enter judgment against an inpleaded third party defendant, even though there would be no federal jurisdiction of a separate action against that defendant. ${ }^{26}$ And although no court has sanctioned use of this "ancillary jurisdiction" theory in interpleader, no

21. See Clark, Code Pleading 473 (2d ed. 1947).

22. Lindsey v. Barron, 6 C.B. 291, 136 Eng. Rep. 1263 (1848) ; Dodge v. Dawson, 19 N.Y. Supp. 904 (Super. Ct. 1892). Such a contingent secondary liability would arise most commonly where an agent with questionable authority to mortgage goods mortgaged them with a third person. The agent might be threatened with adverse claims to the res by the principal denying authority to mortgage and by the mortgagee claiming there was in fact such authority. In addition the mortgagee would have an action against the agent for breach of implied warranty of authority to bind the principal. RESTATENENT, AGENCY $\$ 329$ (1933). But since this theory would be complete only upon failure of the agent to bind the principal, no relief could be given under this claim until the principal recovered in the second stage of interpleader. Lindsey v. Barron, supra. Secondary liability situations appear to be unusual; most of the cases arising under the Interpleader Act deal with primary liabilities. See, e.g., Dee v. Kansas City Life Ins. Co., 86 F.2d 813 (7th Cir. 1936).

23. See note 26 infra and accompanying text.

24. Lynch v. Commissioner, 216 F.2d 574 (7th Cir. 1954) ; New York Life Ins. Co. v. Cooper, 167 F.2d 651, 654 (10th Cir. 1948) ; see Lawlor v. National Screen Serv. Corp., 349 U.S. 322, 326 (1955) ; Note, 64 YALE L.J. 436 (1955).

25. See Indemnity Ins. Co. v. Smoot, 152 F.2d 667 (D.C. Cir. 1945), cert. denied, 328 U.S. 835 (1946) ; Household Finance Corp. v. Rogers, 249 S.W.2d 820 (Ky. 1952).

26. The original jurisdiction may be based either on diversity, Sheppard v. Atlantic States Gas Co., 167 F.2d 841 (3d Cir. 1948), or a federal question, Waylander-Peterson 
reason appears why it should not be utilized. ${ }^{27}$ Finally, if the court were to determine that there were no independent liability, the stakeholder should of course be discharged and the claimants interpleaded. ${ }^{28}$

Not only was the court's version of the independent liability rule unsustainable, but its basic premise, that independent liability was a bar to interpleader under the Act of 1936, was erroneous. Hurlbut and the two district court cases it cited all rely ultimately on Dee v. Kansas City Life Ins. Co., ${ }^{29}$ a Seventh Circuit decision interpreting the Act of $1926 . .^{30}$ But subsequent to that decision the draftsmen of the Act of 1936 explicitly eliminated the ancient interpleader requirement of privity between the claimants, believing that this step necessarily eliminated the independent liability rule. ${ }^{31}$ They apparently reasoned that the latter requirement was merely a special application of the privity rule: that interpleader could be granted only where the claims against the stakeholder had a common origin. When this rule was abolished, the independent liability rule went with it. Use of similar language to abolish the privity rule had previously achieved the desired result in England. ${ }^{32}$ And while it has been pointed out that the privity and independent liability rules are not logically interdependent, ${ }^{33}$ the clear intent of the draftsmen should prevail over logical derivations. Moreover the framers of federal rule 22, who even more clearly intended to abolish the independent liability rule as to nonstatutory interpleader, adopted the language of the Act of 1936 to accomplish their purpose. ${ }^{34}$ If rule 22 is

Co. v. Great No. Ry., 201 F.2d 408 (Sth Cir. 1953). See 3 Moore, Federal Practice II 14.26 (2d ed. 1948).

Impleader is a device by which the defendant, who if liable to the plaintiff will have a right of action created against a third party, may bring that party into the first action so that both claims may be settled together. Horoch v. State, 286 App. Div. 303, 143 N.Y.S. 2d 327 (3d Dep't 1955) ; 3 Moore, op. cit. supra $\Upsilon 14.02$.

27. In an interpleader action ancillary jurisdiction has been used to decide collateral matters between the claimants. The Walmac Co. v. Isaacs, 220 F.2d 108 (1st Cir. 1955); if. Porter v. Warner Holding Co., 328 U.S. 395 (1946).

28. E.g., Dee v. Kansas City Life Ins. Co., 86 F.2d $\$ 13$ (7th Cir. 1936) ; Equitable Life Ins. Co. v. Gilman, 114 F. Supp. 387 (W.D. Mo. 1953).

29. 86 F.2d 813 (7th Cir. 1936).

30. Act of May 8, 1926, c. 273, 44 Stat. 416.

See Hurlbut v. Shell Oil Co., 131 F. Supp. 466 (W.D. La. 1955) ; Equitable Life Ins. Co. v. Gilman, 14 F.R.D. 243 (W.D. Mo. 1953) ; First State Bank v. Citizens State Bank, 10 F.R.D. 424 (D. Neb. 1950). Another case reaching a similar result as the Hurlburt decision, but not cited by the court, is Boice v. Boice, 48 F. Supp. 183 (D.N.J.), aff'd per curiam, 135 F.2d 919 (3d Cir. 1943). This case also ultimately relied on Dee v. Kansas City Life Ins. Co., sutpra note 29.

31. 49 Stat. 1031 (1936), as amended, 28 U.S.C. \$ 1335 (1952); Chafee, Federal Interplcader Since the Act of 1936, 49 YALE L.J. 377, 412 (1940) ; Note, 26 GEo. L.J. 1017, 1021 (1938).

32. Ex parte Mersey Docks and Harbour Bd., [1899] 1 Q.B. 546.

33. Cababe, Interpleader in the High Court of Justice, and in the County COURTS 24 (1900).

34. Compare 49 STAT. 1031 (1936), with FED. R. Crv. P. 22.

Rule 22 was clearly intended to eliminate the independent liability rule. Under rule 22 "no longer are any of the classic requirements of strict bills of interpleader and bills in the 
construed correctly, therefore, the interpretation given the Interpleader Act in Hurlbut, and the cases on which it relied, will give disparate meanings to identical language in related statutes regulating the same problem.

Whatever doubts may exist as to whether the independent liability rule survived enactment of the Interpleader Act should be resolved in favor of its abrogation. For the reasons which prompted development of the rule no longer exist. When the rule was first applied in the nineteenth century, it was required by the stringent limitations on joinder of parties and actions, which prevented litigation of a claim of independent liability in a proceeding to determine title. ${ }^{35}$ Courts reasoned that to grant interpleader to a stakeholder was to discharge him, and therefore a claimant averring independent liability would be deprived of the opportunity to prove his allegations. ${ }^{36}$ The alternative solution of excepting claims of independent liability from the discharge was considered unfair because it would force claimants to pursue such claims in separate proceedings. ${ }^{37}$ Today, however, liberal joinder provisions have removed conceptual obstacles to the trial of logically distinct matters in the same proceeding. ${ }^{38}$ Interpleader should therefore be granted even if it is claimed that the stakeholder is independently liable, and the stakeholder should remain in the proceeding to oppose the claim.

If the independent liability rule is rejected, determination of an independent liability should be made during the second stage of interpleader when the

nature of interpleader in point ..." 3 MOORE, Federal Practice $\{22.04$ (2d ed. 1948). "In fact, [rule 22] . . is interpleader with the shackles of the requirements such as privity, no interest in the stake, and so on, taken away, and made freely available as either a claim or a counterclaim or otherwise." Proceedings of the InstTtuTe at WAshington, D.C., Feneral Rules of Crvil. Procedure 66 (1939); Wright, Joinder of Claims and Partics under Modern Pleading Rules, 36 Minn. L. Rev. 580, 621-22 (1952) ; Comment, 6 Stan. L. Rev. 120, 151 (1953). See also Thomas, Pleadings, Complaint, Answer and Motions: and Rules 17-25 of the Federal Rules of Civil Procedure, 16 ALA. Law. 189, 197 (1955).

In one state where the Federal Rules of Civil Procedure have been adopted, rule 22 has been interpreted to abrogate the independent liability rule. Jersey Ins. Co. v. Altieri, 5 N.T. Super. 577, 68 A.2d 852 (Ch. 1949). But ef. Reid v. Belt, 109 A.2d 137 (Munic. Ct. D.C. 1954) (dictum that strict interpleader requires absence of independent liability). For an explanation of strict interpleader, see note 39 infra.

35. For a discussion of pre-code joinder, see Chafee, Equitable Renedies 107 (1939); Chittr, Pleading 1-44 (1809).

The earliest application of the independent liability rule seems to have been in a fifteenth century case reported in Y.B. Trin. 2 H. 6, f. 16, pl. 19 (1424), discussed in Rogers, Historical Origins of Interpleader, 51 YALE L.J. 924, $940-42$ (1942). But the rule fell into disuse, and its modern application dates from Crawshay v. Thornton, 2 My. \& Cr. 1, 40 Eng. Rep. 541 (Ch. 1837).

36. Crawshay v. Thornton, supra note 35, at 19, 40 Eng. Rep. at 548; Pfister v. Wade, 56 Cal. 43, 49 (1880); Sherman v. Partridge, 4 Duer 646, 649 (N.Y. Super. Ct. 1855). Crazushay v. Thornton, the leading case on the subject and the origin of the American rule, is no longer followed in England. Ex parte Mersey Docks and Harbour Bd., [1899] 1 Q.B. $546,551$.

37. Standley v. Roberts, 59 Fed. 836 (8th Cir. 1894); McClintock, EQuitY $\S 187$ (2d ed. 1948).

38. See notes 44-47 infra and accompanying text. 
claimants are contesting their theories of title. ${ }^{39}$ In an expanded second stage independent claimants would present alternate grounds for recovery-titlè and independent liability. ${ }^{40}$ Consolidating the two questions would avoid an objection suggested by the Hurlbut court that to try independent liability in the first stage might delay unduly the hearing on the claimants' theories of title. ${ }^{41}$ Also, requiring a claimant who alleges independent liability to present his independent claim in one stage, and his title claim in another, would often cause duplication of evidence and other trial inconveniences. ${ }^{42}$ For the same reasons the question of independent liability should not be isolated and preserved for a new third stage, which several commentators have suggested.43 Joinder similar to that proposed for the broadened second stage is already possible through several other procedures. In a declaratory judgment action a stakeholder could join rival claimants as defendants, and in one proceeding determine the questions of title and independent liability. ${ }^{44}$ And in jurisdictions where a suit to

39. See Frumer, On Revising the New York Interpleader Statutes, 25 N.Y.U.L. Rev. 737, 764 (1950); Jersey Ins. Co. v. Altieri, 5 N.J. Super. 577, 68 A.2d 852 (Ch. 1949); Rosenberg v. P. Viane, Inc., 109 Misc. 215, 179 N.Y. Supp. 447 (Sup. Ct. 1919).

In strict interpleader, the stakeholder is discharged at the close of the first stage. See note 2 supra. The type of action under discussion, in which an independent liability is asserted and the stakeholder not discharged, is more correctly styled a bill "in the nature of interpleader." See Klaber v. Maryland Cas. Co., 69 F.2d 934, 940 (8th Cir. 1934); Chafee, The Federal Interpleader Act of 1936: I, 45 YALE L.J. 963, 970 (1936). In such an action the stakeholder may and should be compelled to bear a part of the costs of trial in the second stage. See Century Ins. Co. v. First Nat'l Bank, 133 F.2d 789 (5th Cir. 1943); Chafee, Modernizing Interpleader, 30 YALE L.J. 814, 843 (1921).

40. If the claimant alleging independent liability were successful on his claim of title, it would of course not be necessary to decide the potential independent liability, since the claimant could not recover on both theories. Chafee, Modernizing Interpleader, 30 YaLE L.J. 814,842 (1921).

41. Hurlbut v. Shell Oil Co., 131 F. Supp. 466, 469 (W.D. La. 1955).

42. See Chafee, Modernizing Interpleader, 30 YALE L.J. 814, 842 (1921); Ex parte Mersey Docks and Harbour Bd., [1899] 1 Q.B. 546.

43. Chafee, Modernizing Interpleader, 30 Y ALE L.J. 814, 842 (1921); Note, 14 NEB. L. BunL. 167, 176 (1935). In addition, a three stage interpleader would delay any recovery on independent liability. Moreover, a three stage interpleader would force the stakeholder to participate in the equivalent of two trials. He would often wish to intervene in the second stage to assist the independent liability claimant on his title theory, since a successful claimant could not recover from him on a claim of independent liability. See Chafee, supra at 843. The fact that the stakeholder's citizenship is the same as that of any of the claimants would not defeat federal jurisdiction. Virginia Elec. \& Power Co. v. Carolina Peanut Co., 186 F.2d 816 (4th Cir. 1951). To disallow such a right of intervention might well open the door to a collusive action between the claimants. They might attempt to show good title in the claimant not averring the independent liability in order to preserve the opportunity to make a double recovery from the stakeholder. Such a double recovery is not unlikely since stakeholders are often insurance companies. See Piechuck v. Magusiak, 82 N.H. 429, 135 Atl. 534 (1926), for a discussion of jury reactions to the fact of representation by an insurance company.

44. Federal Deciaratory Judgments Act, 28 U.S.C. \$§ 2201, 2202 (1952). BoRCBARD, Declaratory Judgaments 365 (2d ed. 1941). The principal requisites of a declaratory action-that there be a genuine controversy, that the judgment must serve to clarify the 
quiet title to personalty may be brought by a claimant out of possession, ${ }^{45}$ such a claimant could join other claimants and the stakeholder as defendants, litigating in a single proceeding the questions of title and independent liability. ${ }^{46}$ Although these two remedies seem desirable alternatives to interpleader, their usefulness is restricted, for they require complete diversity of parties. and they provide only for the usual intrastate service of process. ${ }^{47}$

Despite the equity background of interpleader, the right to jury trial should be preserved for the determination of an independent liability which is "legal." Traditionally when claimants have been interpleaded they have been forced to submit their claims to a judge for fact determinations, although in the absence of interpleader they would have been entitled to trial by jury. ${ }^{48}$ In light of that history the Hurlbut court may have adopted its "genuine issue as to law or fact" rule to defeat interpleader and avoid loss of jury trial. ${ }^{49}$ In the declaratory judgment and quiet title suits discussed above. ${ }^{50}$ jury trial is available for the determination of independent liability. ${ }^{51}$ But the history of the development

legal relations in issue and must afford relief from the uncertainty giving rise to the controversy-would be easily satisfied. Panhandle Eastern Pipe Co. v. Michigan Consol. Gas Co., 177 F.2d 942 (6th Cir. 1949) ; Delno v. Market St. Ry., 124 F.2d 965 (9th Cir. 1942). Since declaratory judgment actions are conducted in accordance with the Federal Rules of Civil Procedure, FED. R. CIv. P. 57, the claimants could be joined as defendants under rule 20 because the relief would arise from the same transactions and would involve common questions of fact and law concerning title. The fact that separate theories would give rise to one of the demands for relief would not matter because the common law limitations on joinder of theories have been liberalized by the Federal Rules of Civil Procedure to permit such a joinder. See Hynd v. McGraw, 11 F.R.D. 82 (S.D.N.Y. 1950) ; Hopper v. Lentien \& Mitchell, Inc., 52 F. Supp. 319 (S.D. Cal. 1943), rev'd on other grounds, 146 F.2d 364 (9th Cir. 1944).

45. Actions to quiet title must be brought in accordance with state law. See Clark v. Allen, 331 U.S. 503, 517 (1947). While at common law actions to quiet title could be brought only for realty, Flager v. Spellman, 15 F.2d 292 (2d Cir. 1926) (dictum), and only by a plaintiff in possession of the property, MCCLINTOCK, EquiTY $\$ 193$ (2d ed. 1948), some modern statutes allow quiet title actions to personalty and dispense with the requir:ment that the plaintiff have possession of the property. E.g., Cal. Cone Civ. Proc. $\$ 738$ (1949) ; Thornton v. Middletown Education Corp., 21 Cal. App. 2d 707, 70 P.2d 234 (1937).

46. See Hynd v. McGraw, 11 F.R.D. 82 (S.D.N.Y. 1950) ; Callinan v. Federal Cash Register Co., 3 F.R.D. 177 (W.D. Mo. 1942).

47. Normally a federal court's process is confined to the territorial limits of the stats: in which it sits. Munter v. Weil Corset Co, 261 U.S. 276 (1923); FED. R. CIV. P. 4(f)* In declaratory suits federal courts have only intrastate process since no special legislation provides for interstate service. Reiter v. Illinois Nat'1 Cas. Co., 213 F.2d 946 (7th Cir. 1954). Hence, unless there were voluntary appearances, Craig v. Baird, $109 \mathrm{~F}$. Supp. $4 \%$ (E.D. Mich. 1952), or agents within the state to receive process, Williams v. Camplell Soup Co., 80 F. Supp. 865 (W.D. Mo. 1948), it might be impossible to serve some of the parties in either a suit to quiet title or a declaratory judgment action.

48. Frumer, supra note 39 , at 781 .

49. E.g., Empire Engineering Corp. v. Mack, 217 N.Y. 85, 94-95, 111 N.E. 475, 478 (1916) ; Frumer, supra note 39, at 781 n.194.

50. See notes 44-47 supra and accompanying text.

51. See Ring v. Spina, 166 F.2d 546 (2d Cir.), cert. denied, 335 U.S. 813 (1948); United States Fidelity \& Guaranty Co. v. Koch, 102 F.2d 288 (3d Cir. 1939) ; Ford v. C. E. 
of interpleader is no barrier to permitting jury trial on issues of independent liability. For, while past reforms extending the availability of interpleader have in a sense encroached upon the right to trial by jury, they have resulted in trial by the court only on the same questions of title that have historically been within the province of the court in interpleader. ${ }^{52}$ On the other hand, federal procedure generally preserves jury trial for legal issues, ${ }^{53}$ and it is usually a simple matter to isolate such issues and thus to determine the appropriate mode of trial. ${ }^{6 \cdot 4}$ There is therefore no reason why jury trial should not be preserved when "legal" issues of independent liability are tried in interpleader suits.

Relief under the Federal Interpleader Act is not and should not be barred by an independent liability. When such a liability is claimed, the trier of fact should determine its existence during the litigation concerning title. But if judges continue to regard the absence of independent liability as a requirement for interpleader, they should at least reject the Hurlbut rule, and should make findings of liability before denying interpleader. They would thus accomplish the second best result of confining the rule of independent liability to its usual narrow scope pending a second attempt to abrogate the rule by statute.

Wilson \& Co., 30 F. Supp. 163 (D. Conn. 1939), aff'd, 129 F.2d 614 (2d Cir. 1942); 5 Moore, Federal Practice $\int 38.13$ (2d ed. 1951).

52. It was originally a condition of federal interpleader that the titles of the claimants have a common origin. Bartlett v. His Imperial Majesty The Sultan, 23 Fed. 257 (C.C. S.D.N.Y. 1885). But the extension of equity jurisdiction by the abolition of this requirement has not introduced jury trial to interpleader. See, e.g., Irving Trust Co. v. Marine Midland Trust Co., 47 F.2d 907 (S.D.N.Y. 1931), vacation denied, 56 F.2d 385 (S.D.N.Y.), appeal dismissed sub nom. Marine Midland Trust Co. v. Eybro Corp., 58 F.2d 165 (2d Cir. 1932) ; cf. Humble Oil \& Refining Co. v. Sun Oil Co., 191 F.2d 705, 713, 718 (5th Cir. 1951), cert. denied, 342 U.S. 920 (1952) (action to quiet title liberalized by statute). The reasoning of these cases would lead to trial by the court on the issue of title. However, if an equity court is given jurisdiction of a legal remedy the right to jury trial is preserved. See Scott v. Neely, 140 U.S. 106 (1891) ; Favorite Films Corp. v. Warner Bros. Pictures, Inc., 13 F.R.D. 452 (S.D.N.Y. 1952) ; Ransom v. Staso Milling Co., 2 F.R.D. 128 (D. Vt. 1941).

53. Fer. R. Crv. P. 38, 39. See, e.g., Dice v. Akron, C. \& Y.R.R., 342 U.S. 359 (1952); Bailey v. Central Vermont Ry., 319 U.S. 350 (1942).

54. See 5 Moore, Federal Practice $\int 38.13$ (2d ed. 1951); Chafee, Broadening the Second Stage of Interpleader, 56 HARv. L. Rev. 541, 552 (1943).

If both legal and equitable theories depend on a common fact so that they cannot be separated, the jury will decide the fact for both theories. Leimer v. Woods, 196 F.2d 828, 834 (8th Cir. 1952). 